\title{
Performance Evaluation of the Effect of pH and Temperature on the Biogas Yield of Co-Digestion of Pig Manure and Water Hyacinth
}

\author{
Nse Peter Essang \\ Department of Petroleum and Natural Gas Processing Engineering, \\ Petroleum Training Institute, Effurun, Nigeria
}

\begin{abstract}
In this research work, the effect of $\mathrm{pH}$ and temperature on the biogas yield of co-digestion of Pig manure and water hyacinth were investigated experimentally in laboratory scale anaerobic bioreactors. The co-digestion was run for a Hydraulic Retention Time thirty six days. The volumetric yield of biogas was noted once there is biogas build up at regular intervals using water displacement method. A total of ten evacuations were made and the data obtained was used to evaluate the effect of the aforementioned anaerobic digestion parameters. The experimental results revealed that a neutral $\mathrm{pH}$ value of $7 \mathrm{yielded}$ optimum biogas yields compared to a $\mathrm{pH}$ value above and below 7. Moreover, from all the experimental mesophilic temperature used in this research work, an optimum mesophilic temperature of 37 oC favoured the optimum biogas yield.
\end{abstract}

KEYWORDS: pH, Biogas yield, Hydraulic retention time, Pig manure, Water Hyacinth, Optimum biogas yield

\section{INTRODUCTION}

The increasing demand for energy, inadequate availability of conventional energy supplied such as fossil and wood fuel resources, increase in crude oil prices, and the increasing concern for environmental issues have challenged researchers across the world to develop an alternative energy means that is clean and sustainable energy through the utilization of non-conventional renewable energy sources [1-4]. In this respect, biogas production from anaerobic digestion or co-digestion process of biodegradable organic waste will be a welcome development. The anaerobic digestion (AD) process has become an increasingly vital industrial process. The production of biogas from $\mathrm{AD}$ process is of growing interest across the world [5-7] and this is due to decline in wood and fossil fuel resources and their resulting effect on the ozone layer [8]. Worldwide greenhouse gas (GHG) emissions from biomass have doubled since the 1960 s and could further increase by $30 \%$ if nothing is done about it. Anaerobic digestion is widely as a treatment option for the disposal of municipal solid waste on a par with the composting technologies. It mainly combines with the energy recovery benefits, greenhouse gas mitigation and produces stable end products, which can be further upgraded as compost for land use applications [9].

To optimize the rate of biogas yield, it is essential to optimize the process parameters involved in the digestion process. Many researchers investigated the effects of process parameters involved in the biogas production and reported their findings. Orhorhoro et al. [10] investigated the effect organic loading rate (OLR) on biogas yield from food waste, water hyacinth, and cow dung, waste water from abattoir, poultry dropping and pig dung. Their experiment was conducted within a mesophilic temperature range of $36^{\circ} \mathrm{C}$ $37^{\circ} \mathrm{C}$, percentage total solid (\%TS) of $9.98 \%$ and percentage volatile solid (\%VS) of $78 \%$. pH meter was used to monitored the daily $\mathrm{pH}$ reading of the slurry. They reported that the quantity of biogas yield from the feedstock increases with increasing organic load rate to the optimum value of 1.5 $\mathrm{kg} / \mathrm{m}^{3}$ and started decreasing above the optimum value for a single stage $\mathrm{AD}$ reactor for a three-stages continuous $\mathrm{AD}$ reactors there was a continuous increase in biogas yield with a successive increase in OLR from $1-5 \mathrm{~kg} / \mathrm{m}^{3}-3.0 \mathrm{~kg} / \mathrm{m}^{3}$. Sivakumar et al. [11] investigated the effect of $\mathrm{pH}$ using spoiled milk as substrate and reported that the substrate with $7 \mathrm{pH}$ resulted better biogas yield. Kafle et al [12] investigated the effect of co-digestion of Kimchi factory waste silage and swine manure under mesophilic temperature condition. The results suggested that Kimchi factory waste could be effectively treated by making silage, and the silage could be used as a potential co-substrate to enhance biogas production from swine manure digester. Deepanraj et al. [13] studied the effect of temperature on biogas production using food waste in a lab scale batch reactor and found that the operating temperature of $50^{\circ} \mathrm{C}$ achieved maximum biogas yield. Orhorhoro et al. [14] analyzed of the effect of Carbon/Nitrogen $(\mathrm{C} / \mathrm{N})$ ratio on the performance of biogas yields for non-uniform multiple feed stock availability and composition in Nigeria. The results obtained from their research work show that $\mathrm{C} / \mathrm{N}$ ratio of substrates affects hydraulic retention time, biogas yield and the rate of frequency of evacuation. Therefore, for a better biogas yield, combination of low and high $\mathrm{C} / \mathrm{N}$ ratio substrates is recommended. Sumardiono et al. [15] investigated the effect of COD/N ratios of substrate and $\mathrm{pH}$ control to biogas production from vinasse. Their study used anaerobic digestion-laboratory scale at room temperature in batch system. Urea was added as nitrogen source to adjust COD/ $\mathrm{N}$ ratios of $400 / 7,500 / 7,600 / 7$, and 700/7. Initial $\mathrm{pH}$ for all variables was adjusted 7.0 by using $\mathrm{NaOH}$ solution. The results obtained reveal that biogas formed at COD/N ratio of control variable $(1436 / 7) ; 400 / 7 ; 500 / 7 ; 600 / 7$; $700 / 7$ were $3.673 ; 4.909 ; 6.079 ; 6.096 ; 5.631 \mathrm{~mL} / \mathrm{g}$ COD respectively. $\mathrm{pH}$ profiles for all variables were decreasing from beginning until ending of fermentation. With controlled $\mathrm{pH}, \mathrm{pH}$ of substrates was maintained at neutral condition, so methanogenic bacteria could grow well in the digesters. Consequently biogas formed at controlled $\mathrm{pH}$ was larger 
than that at uncontrolled $\mathrm{pH}$. The values of COD removal for COD/N ratio of control variable; 400/7; 500/7; 600/7; $700 / 7$ were $1.27 \pm 0.43 ; 1.59 \pm 0.43 ; 2.85 \pm 0.39 ; 3.21 \pm 0.49$; $2.22 \pm 0.39 \%$ respectively at uncontrolled $\mathrm{pH}$, whereas at controlled $\mathrm{pH}$ the values of these were $11.98 \pm 0.56$; $12.82 \pm 0.56 ; \quad 12.03 \pm 0.94 ; \quad 13.05 \pm 0.35 ; 12.61 \pm 0.56 \%$ respectively. However, enough research works were not reported on biogas yield performance of co-digestion of animal manure and seed weeds, thus this research work.

\section{Materials and Methods}

Water hyacinth used in this research work was harvested from River Ethiope, Boboroku- Jesse, Nigeria (Figure 1), and the Pig manure collected from Pig farm, Jesse, Nigeria (Figure 2). The experiment was carried out in laboratoryscale reactors as depicted in the schematic diagram (Figure 3 ). The volume of each reactor was $2,000 \mathrm{ml}$ with a working volume of $1250 \mathrm{ml}$. All the reactors were purged with nitrogen before start-up in order to create anaerobic condition. The mixing was continuous and this was achieved using magnetic stirrer. The experiment was subjected to mesophilic temperature range of $36{ }^{\circ} \mathrm{C}$ as recommended by Ebunilo et al. [2]. A pH meter was monitored using electronic $\mathrm{pH}$ metering (Figure 4).

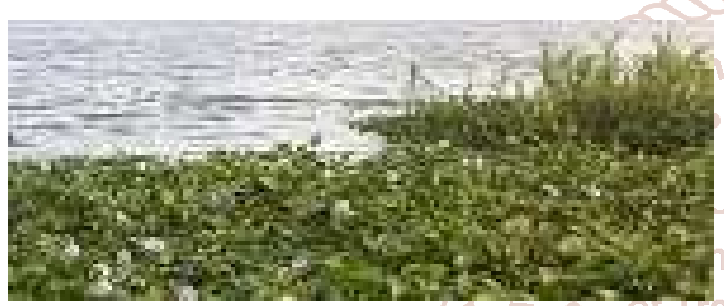

Figure 1: Water Hyacinth
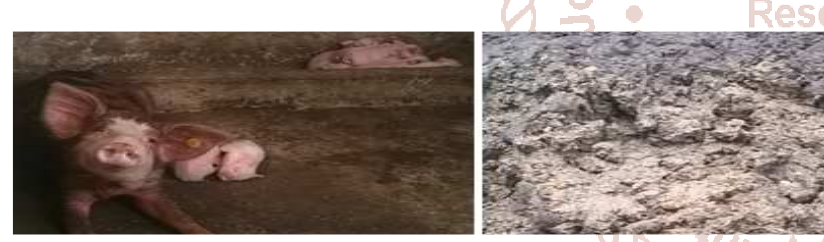

Figure 2: Pig Manure

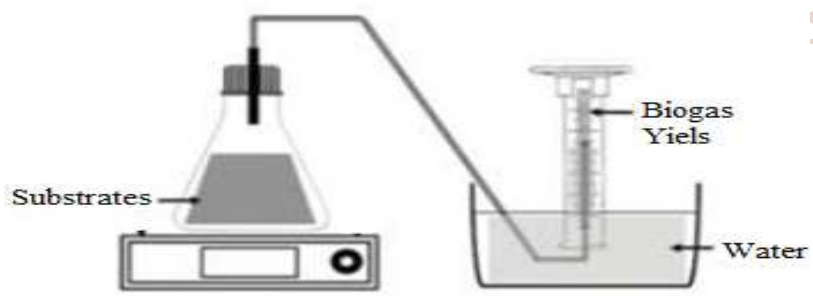

Figure 3: Experimental Setup

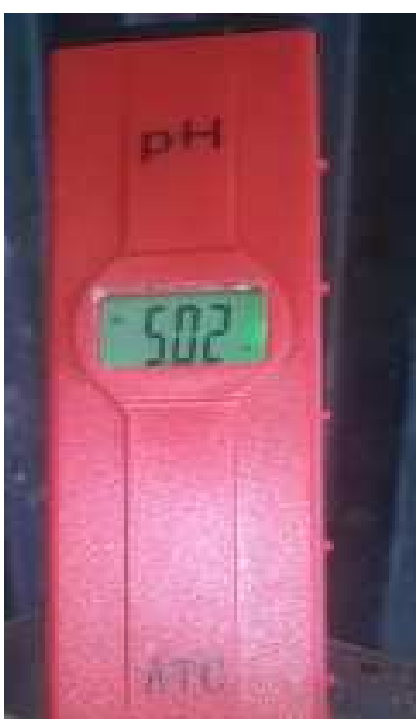

Figure 4: pH Meter

\section{Results and Discussion}

The roots of the water hyacinth were gently detached and the remaining parts properly washed and grinded using a grinding machine. The grinded water hyacinth was codigested with the Pig manure to form slurry. According to Orhorhoro et al., [16], grinding increased the surface area of contact for the microbial activity, so that biogas yield would start within the shortest possible time. Preparation of fermentation of slurry was by addition and vigorous mixing of total substrate with an equivalent amount of water needed for maximum yield. The ratio of total substrate to water was 1:2 as recommended by Ebunilo et al., [17]. The amount of biogas yield was measured once there is an indication of biogas build up in the measuring cylinder. The measuring cylinder was then inverted with the gas pressure displacing equal amount of water and the readings were recorded. This procedure was repeated ten (10) times to ascertain the total volume of biogas produced. A pH meter was used to monitor the $\mathrm{pH}$ of the system. To measure the $\mathrm{pH}$ of the slurry, the probe (glass electrode) was inserted into the sample of the slurry after each evacuation. The results obtained show that optimum biogas yield was obtained at $\mathrm{pH}$ neutral reading of 7 . Furthermore, a $\mathrm{pH}$ values below and above the optimum biogas yielding $\mathrm{pH}$ value of 7 brings about drops in biogas yield.

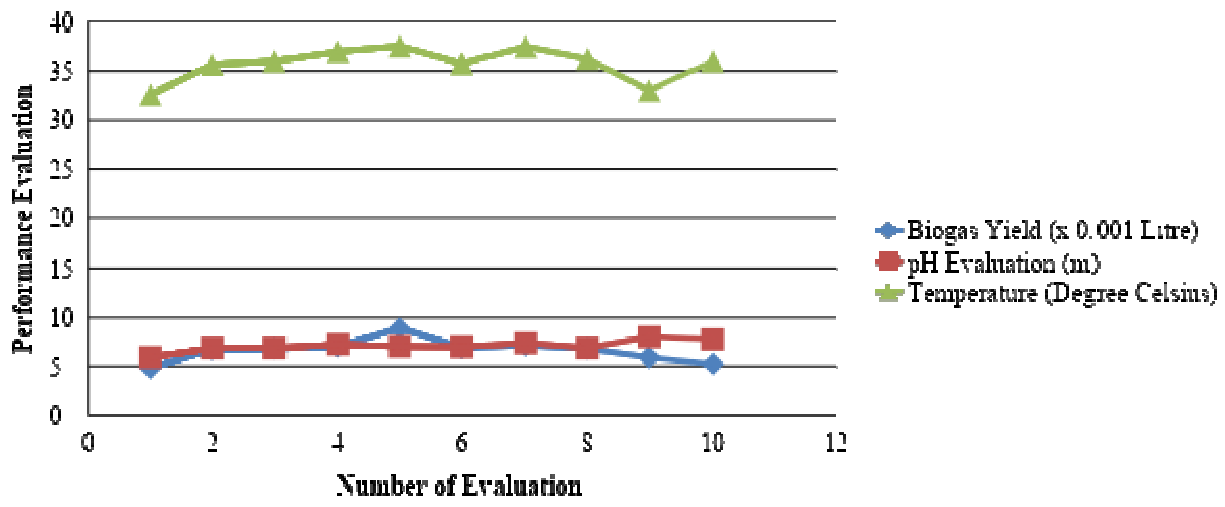

Figure 5: Results of Performance Evaluation 
It was also observed that temperature affect the biogas yield throughout the hydraulic retention time. An optimum biogas yields was obtained at optimum mesophilic temperature of $37{ }^{\circ} \mathrm{C}$, and this agree with the research work of Ebunilo et al. [2].

\section{Conclusion}

In this research work, the effect of $\mathrm{pH}$ and temperature on biogas yield from co-digestion of Pig manure and water hyacinth were successfully evaluated The results obtained from the research work show that an optimum biogas yield is favored with a slurry $\mathrm{pH}$ of neutrality value of 7. Moreover, for an optimum biogas yield, an optimum mesophilic temperature is required. Besides, the abundant water hyacinth in River Ethiope and Pig manure in Jesse can be used for production of biogas which can be used in place of conventional energy such as wood and fossil fuel.

\section{References}

[1] E. K. Orhorhoro, P. O. Ebunilo, E. G. Sadjere. Development of a Predictive Model for Biogas Yield Using Artificial Neural Networks (ANNs) Approach. American Journal of Energy and Power Engineering, 2017; 4(6): 71-77

[2] P. O. Ebunilo, E. K. Orhorhoro, V. Oboh, P. U. Onochie. Effect of Temperature on Biogas Yields Using SouthSouth Nigeria as a Case Study. International Journal of Technology Enhancements and Emerging Engineering Research, 2016,4(3), pp. 50-54

[3] E. K. Orhorhoro, O. W. Orhorhoro, A. E. Ikpe. A Study of Solar Energy Potential in Sapele, Nigeria. Int. J. of Thermal \& Environmental Engineering, 13(2), 2016, 129-133

[4] G. K. Kafle, S. Bhattarai, S.H. Kim, L. Chen, Anaerobic digestion of Chinese cabbage waste silage with swine manure for biogas production: batch and continuous study, Environmental Technology, 35, 2014, 27082717.

[5] E. K. Orhorhoro, P. O. Ebunilo, E. G. Sadjere. Experimental Determination of Effect of Total Solid (TS) and Volatile Solid (VS) on Biogas Yield. American Journal of Modern Energy, 2017, 3(6): 131-135

[6] W. Qiao, X. Yan, J. Ye, Y. Sun, W. Wang, Z. Zhang. Evaluation of biogas productio from different biomass wastes with/without hydrothermal pretreatment. Renewable Energy, 36, 2011, 3313-3318

[7] T.Subramani, M. Nallathambi. Mathematical Model for Commercial Production of Bio-Gas from Sewage Water and Kitchen Waste. International Journal of Modern Engineering Research (IJMER), 2 (4), 2012, 1588-1595

[8] P. O. Osunde, P. O. B Ebunilo, E. K. Orhorhoro. Preliminary Evaluation of a Biogas Purification Filter Suitable for use in Nigeria Journal of Scientific and Engineering Research, 2017, 4(10), 125-134

[9] E. Dogan, G.N. Demirer, Biogas generation by twophase anaerobic digestion of organic fraction of municipal solid waste, Journal of Renewable \& Sustainable Energy, 4, 2012, 063131

[10] E. K. Orhorhoro, P.O. Ebunilo, E. G. Sadjere. Effect of Organic Loading Rate (OLR) on Biogas Yield Using a Single and Three-Stages Continuous Anaerobic Digestion Reactors. International Journal of Engineering Research in Africa, Vol. 39, pp. 147-155

[11] H. Raheman, S. Mondal, Biogas production potential of jatropha seed cake, Biomass and Bioenergy, 37, 2012, pp.25-30.

[12] P. Sivakumar, M. Bhagiyalakshmi, and K. Anbarasu, Anaerobic treatment of spoiled milk from milk processing industry for energy recovery-A laboratory to pilot scale study, Fuel, 96, 2012, 482-486.

[13] G. K. Kafle, S.H. Kim, Sung, Batch anaerobic codigestion of Kimchi factory waste silage and swine manure under mesophilic conditions, Bioresouce Technology, 124, 2012, 489-494.

[14] O. W. Orhorhoro, E. K, Orhorhoro, P.O. Ebunilo, P.O. Analysis of the effect of carbon/nitrogen $(\mathrm{C} / \mathrm{N})$ ratio on the performance of biogas yields for non-uniform multiple feed stock availability and composition in Nigeria. International Journal of Innovative Science, Engineering \& Technology, 3(5), 2016, 119-126

[15] - S. Sumardiono, I. Syaichurrozi, Budiyono1 and S. B. Sasongko. The Effect of COD/N Ratios and pH Control to Biogas Production from Vinasse. International Journal of Biochemistry Research \& Review 3(4): 401413,2013

[16] E. K. Orhorhoro, P. O. B. Ebunilo, E. G. Sadjere. Design of Bio-Waste Grinding Machine for Anaerobic Digestion (AD) System. European Journal of Advances in Engineering and Technology,4 (7), 2017, 560-568

[17] P. O. Ebunilo, S. A. Aliu, E. K. Orhorhoro. Performance Study of a Biogas Pilot Plant using Domestic Wastes from Benin Metropolis. International Journal of Thermal \& Environmental Engineering volume 10(2), 2015, 135-141 